A

\title{
A Case Stud: Inter-decadal changes in cropping pattern and relative shifts in favour of superior crops in Rajasthan
}

\section{R.S. PATODIYA}

Article Chronicle : Received : 24.05.2014; Accepted : 30.01 .2015

Key Words :

Cropping pattern, Cereals, Oilseeds, Nonfood grain
SUMMARY : Relative position of various crops over time in the cropping pattern of the state, bajra ranked first followed by wheat, rapeseed and mustard, gram and maize. Among the cereals, bajra and wheat dominated the cropping patter in both pre and post green revolution period. Gram dominated among the pulses as it covers about 50 per cent of total area under pulses in the state. Oilseeds accounts about two third of total area under non-food grain crops.

How to cite this article : Patodiya, R.S. (2015). Inter-decadal changes in cropping pattern and relative shifts in favour of superior crops in Rajasthan. Agric. Update, 10(1): 81-83.

Author for correspondence :

\section{R.S. PATODIYA}

Krishi Vigyan Kendera (M.P.U.A.T.) RAJSAMAND

(RAJASTHAN) INDIA

Email: patodiya1959

mpuat@gmail.com 